\title{
En Uygun Arazi Kullanım Planlarının CBS ile İncelenmesi: Sivas İli Dikmencik Köyü Örneği
}

\author{
İlknur SAYKILI ${ }^{1}$, Anıl Can BİRDAL ${ }^{1}$, Tarık TÜRK ${ }^{1^{*}}$ \\ ${ }^{1}$ Cumhuriyet Üniversitesi, Geomatik Mühendisliği Bölümü, Sivas \\ (ilknursaykili35, anilcanbirdal, tarikturk@gmail.com) ORCID ID 0000-0002-4459-7967, \\ ORCID ID 0000-0002-2416-2296, ORCID ID 0000-0002-2671-7590
}

\begin{abstract}
Öz
Arazi uygunluk analizi, en uygun arazi kullanımı amacına yönelik arazi kullanımının esaslarını belirleyen bileşenlerden biridir. En uygun arazi kullanımı, bölgeye ait topografik etmenler ve tarımsal veriler ışığında, çiftçi alışkanlıkları ile bölgenin doğal ve kültürel potansiyeli dikkate alınıp ekolojik esaslar gözetilerek hazırlanan bir arazi kullanımının tercih edilmesi ile sağlanır.

$\mathrm{Bu}$ çalışmada en uygun arazi kullanım planlanmasının CBS ile belirlenmesine yönelik bir uygulama gerçekleştirilmiştir. Sivas İli Merkez İlçe Dikmencik köyüne ait kadastral sınırlar içerisinde yer alan tarımsal alanlar ile mera ve orman arazileri olmak üzere üç ana sınıflandırmaya tabii tutulan arazilerin arazi kullanım biçimleri dikkate alınmıştır. Daha sonra, en uygun arazi kullanım haritaları üretilmiş ve sonuçlar günümüzdeki mevcut arazi kullanım özellikleri ile karşılaştıılmıştır. Elde edilen sonuçlara göre çalışma alanındaki arazilerin büyük bir bölümünün en uygun arazi planlamasına uygun bir şekilde kullanılmadığı tespit edilmiştir.
\end{abstract}

Anahtar Kelimeler: Arazi uygunluk analizi, CBS, En uygun arazi kullanımı

\section{Investigation of the Optimum Land Use Plans by GIS: A Case Study in Sivas City}

\begin{abstract}
Land suitability analysis is one of the components that determines the principles of land use for the purpose of optimal land use. Optimum land use is achieved by considering the natural and cultural potential of the region and by preferring the suitable land use for the ecological structure with topographical factors and agricultural data.

In this study, an implementation was performed to determine the most suitable land use plan with GIS. Land use patterns of the three main categories of agricultural land, pasture and forest within the cadastral borders belonging to the Dikmencik village of the Sivas province Central District were taken into consideration. Subsequently, the most appropriate land use maps were produced and the results were compared with the current land use characteristics. According to the results obtained, it has been determined that a large part of the land in the study area is not appropriately used for optimal land planning.
\end{abstract}

Keywords: Land suitability analysis, GIS; Optimal land use

\section{GíRiș}

Arazi Kullanım Planları; Toprak ve arazi etütlerine dayanılarak yapılan yerel, bölgesel ve ülkesel ölçekte tarım, orman ve mera arazileri, özel kanun vasitası ile sınırlandırılmış araziler, sanayi konut ve turizm alanları, ekonomik ve sosyal amaçlı altyap1 alanlarında, farklı arazi kullanım biçimleri ile mevcut kullanım türlerini ve sürdürülebilir arazi yönetim biçimlerini gösteren harita ve raporlardan oluşturulan

\footnotetext{
* Sorumlu Yazar

Bu çalışma IX. TUFUAB 2017 Teknik sempozyumunda sunulmuş olup başka bir yerde yayınlanmamıştır.
} 
planlardır (Akten 2008). Arazi kullanım planlaması ile ilgili yapılan çalışmalar incelendiğinde arazilerin yanlış kullanımının yanı sıra doğal ve kültürel kaynakların yanlış kullanımından oluşan sorunlara çözüm aranıp sürdürülebilirliği sağlamak amacıyla birtakım çalışmalar yapılmıştır. Cengiz vd. (2013), Gökçeada'da ki arazilerin etkin ve sürdürülebilir kullanılabilmesi amacıyla en uygun arazi kullanımı uygunluk analizi gerçekleştirmiş ve analiz sonucunda orman, çayır-mera ve tarımsal faaliyetler için önerilen alanları sirasiyla \% $35.06, \% 21.21$ ve \% 17.17 olarak tespit etmişlerdir. Akbulak (2010), Yukarı Kara Menderes Havzası'nda arazi kullanımı uygunluk analizi yapmıştır. Çalışmada tarım, çayır-mera ve orman olmak üzere üç farklı arazi kullanım türünü dikkate almıştır. Önerilen en uygun arazi kullanımı ile mevcut arazi kullanım durumu karşılaştırıldığında ise mevcut arazi kullanımındaki tarım alanlarının önerilen tarım arazilerinden fazla olduğunu, orman ve çayır-mera alanlarının ise daha düşük olduğunu ortaya koymuştur. Cengiz (2009), Kuzeybatı Türkiye Dümrek köyü için arazi kullanım uygunluğu analizini Analitik Hiyerarşi Süreci (AHP) ve Coğrafi Bilgi Sistemleri (CBS) kullanarak değerlendirmiş tarım, çayır-mera ve orman alanları için uygunluklarını belirlemiştir. Dümrek'in kırsal kalkınması için arazi kullanımı tercihleri sırasıyla tarım, orman ve çayırdır. Zengin ve Yilmaz (2007), Ardahan Kura Nehri ve yakın çevresinde ekolojik yapıya uygun Optimal Alan Kullanımlarını belirlemek amacıyla bir çalışma gerçekleştirmiştir. $\mathrm{Bu}$ çalışma sonucunda doğal ve kültürel kaynakların hızla tükenmekte olduğunu ve mevcut kaynakların da yanlış alan kullanımları nedeniyle yok olma tehlikesiyle karşı karşıya kalmakta olduğunu vurgulamıştır. $\mathrm{Bu}$ sorunların üstesinden gelebilmek amaciyla tarım, çayır, mera, orman, yerleşim, turizm ve rekreasyon ile koruma alanlarından oluşan yedi farklı alan kulanım türünü hesaba katarak ekolojik uygunluk haritaları oluşturmuştur.

Ülkemizde çoğu zaman tarımsal arazi kullanımları rasyonel bir plan doğrultusunda kullanılmamaktadır. Bunun sonucu olarak toprak ve topografik özelliklerine göre en verimli araziler imar alanı ya da endüstri ve sanayi bölgeleri için yatırım yeri olarak kullanılmakta, öte yandan da orman ve mera arazileri ise tecavüzlerle tarım alanı olarak kullanılmaya çalışılmaktadır. Gerek ülkemizde gerekse gelişmekte olan ülkelerde bulunan tarımsal niteliğe sahip araziler, plansız arazi kullanımı, yoğun toprak işleme sonucu toprak erozyonu, sanayi ve imar sektöründeki gelişmelere paralel olarak tarım dışı taleplerin artması ile gün geçtikçe oransal olarak azalmaktadır. Yine toprağ 1 kullanım hakkını elinde bulunduran kırsal bölgelerdeki eğitim sorunu, dünya üzerinde yaşanan hızlı nüfus artış1, sektörel kurumsal desteklerin yetersizliği veya olmayışı vb. nedenler ile tarımsal niteliğe sahip araziler baskı altında bulunmaktadır.

Arazilerin yanlıș kullanım planlaması ile yönetilmesi sonucu, birbirlerine ekonomik anlamda bağl1 olan sektörler arasında uyumsuzluk görülmektedir. Yine plansız arazi kullanımı uygulamalarının yanlış tarımsal teknik ve mekanizasyon uygulamaları ile birleşerek neden olduğu sonuçlardan erozyonun olumsuz etkisi de yadsinamaz. Plansız arazi kullanımı altında bulunan toprakların rüzgâr ve su kuvveti nedeni ile taşınması, bu durumun oluşabilecek sel, toprak kayması ve taşkın gibi doğal afetlere davetiye çıkarmaktadır. Yine taşınan üst verimli tabakaya ait toprak, tarımsal alanlardan kaybolarak yerleşim yerlerini, baraj ve liman gibi tarım dışı alanlara taşınmakta ve bu bölgeleri doldurmaktadır. Bitki örtüsü kaybolmuş hatalı toprak işleme yapılmış ve arazi kullanım planlarından yoksun özellikle eğim oranı yüksek arazilerde bu taşınmanın neticesi olarak çoğu bölgede ana kayaç yapısının ortaya çıktığı, tarım toprağının tamamen kaybolduğu görülmektedir. $\mathrm{Bu}$ durum toprağın su ve organik madde tutma kapasitesinin kaybolmasına, çoraklaşmaya ve nihayetinde tarımsal üretime uygun olmayan, çölleşmiş ve kurak alanlar oluşmasına neden olmaktadır. $\mathrm{Bu}$ tablo nihayetinde tarımsal üretim kaybı, kırsal kalkınmanın yavaşlaması ya da durmas1, kırsaldan kente göçün artması, tarım arazilerinin nitelik ve nicelik olarak azalmas1 ve değerlerinin düşmesi vb. gibi birçok ekolojik, ekonomik, sosyal, ve kültürel sorunları da beraberinde getirmektedir. Sonuç olarak doğal kaynaklarımız bozulmakta ve sürdürülebilir kırsal kalkınmanın ana 
lokomotifi olan tarım sektörü tehlikeye girmektedir.

$\mathrm{Bu}$ olumsuzlukların önüne geçebilmek için, temeli araziye dayalı sektörler olan tarım, orman, ulaşım, sanayi vb. sektörlerin mevcut çalışma alanlarının ekonomik, kültürel, sosyal ve çevresel etmenler dikkate alınarak kesin bir şekilde belirlenmesi ve bu doğrultuda en uygun arazi kullanım planı ve haritalarının oluşturulması gerekmektedir. Bilimsel veriler 1şığında hazırlanacak bu planlamaların, hızla artan nüfusun beklentilerine cevap vermesi, ekosistemlerin ve hizla azalan tarımsal arazilerin bugünkü ve gelecekteki verimliliğinin korunması arasında denge mekanizması olması, bu sayede mevcut ve optimum arazi kullanım biçimlerinin ortaya konarak sürdürülebilir arazi kullanımını gerçekleştirmesi gerekmektedir.

Konuya kırsal yörelerin mevcut durumu açısından bakıldığında, çalışma alanı olan köylerde yaşayan halkın tarım ve hayvancılık ile uğraştığ1 ve bu arazilerinden elde edilen ürünlerle geçimini sağladığı görülmektedir. $\mathrm{Bu}$ nedenle kırsal yerleşim yerlerindeki tarım, orman ve mera arazilerinin tanımlarına uygun bir şekilde mekânsal tahsisini gerçekleştiren planların yapilması ve bu planlar doğrultusunda yönetilmesinin sağlanması önemli bir konudur. Ancak bu şekilde arazi kaynakları daha etkin ve verimli bir biçimde kullanılacak ve sürdürülebilir kırsal kalkınma hamlesinin başlaması mümkün olacaktır (URL1, 2017).

$\mathrm{Bu}$ çalışmada tarım, orman ve mera alanlarının, çalışma alanını kapsayan arazideki adres ve yerleşkelerinin (konumlarının) CBS yardımıyla nasıl belirlenebileceği konusunda arazi kullanımı planlaması gerçekleştirilmiştir. Belirli bir arazi parçasına yönelik arazi kullanım kararları, bu arazinin arazi kullanım şekli için uygunluğuna bağlıdır. Bu nedenle bu adımda öncelikle arazi uygunluk değerlendirmeleri gerçekleștirilmiş ve bu amaç doğrultusunda ağırlıklı çakıştırma tekniği kullanılmıştır.

Böylece çalışma alanındaki mevcut arazi üzerinde bulunan tarım, orman ve mera alanları için potansiyel uygunluk durumu ortaya konmuş ve arazi uygunluk haritaları oluşturulmuştur. $\mathrm{Bu}$ değerlendirmelere bağl1 olarak, arazilerin alternatif sektörlere ya da tarım dışı tahsisi yönünde karar verme problemi dikkate alınmıştır. $\mathrm{Bu}$ doğrultuda öncelikle her bir sektöre yönelik arazi uygunluk haritaları kullanılarak arazi uygunluklarına dayalı arazi kullanım tahsisi gerçekleştirilmiştir. Daha sonra, ilgili sektörlere tahsis edilmesi gereken alanlar dikkate alınarak en uygun arazi kullanım tahsisine yönelik çözümlemeler gerçekleştirilmiştir.

\section{2. ÇALIŞMA ALANI}

Çalışma bölgesi olan Sivas ili, coğrafi konum olarak $35^{\circ} 50^{\prime}$ ve $38^{\circ} 14^{\prime}$ doğu boylamları ile $38^{\circ} 32^{\prime}$ ve $40^{\circ} 16^{\prime}$ kuzey enlemleri içerisinde yer almaktadır. Sivas ili 28.488 km2'lik yüzölçümüyle, Türkiye'nin toprak bakımından ikinci büyük ilidir. İl topraklarının Kızılırmak havzasına giren bölümünde Karadeniz iklimi, Fırat Havzasına giren bölümde ise, Doğu Anadolu iklimi egemendir.

Çalışma alanına konu Dikmencik Köyü ise Sivas İl Merkezine yaklaşık 17,5 km uzaklıkta yer alan, 25 hane ve 75 nüfuslu bir yerleşim yeridir. Köyün iklimi karasal özellik gösteren bir yapıda olup yazlar sıcak ve kurak, kışlar soğuk ve kar yağışlidır. Köyün geçim kaynağ1 tarım ve hayvancılıktır.

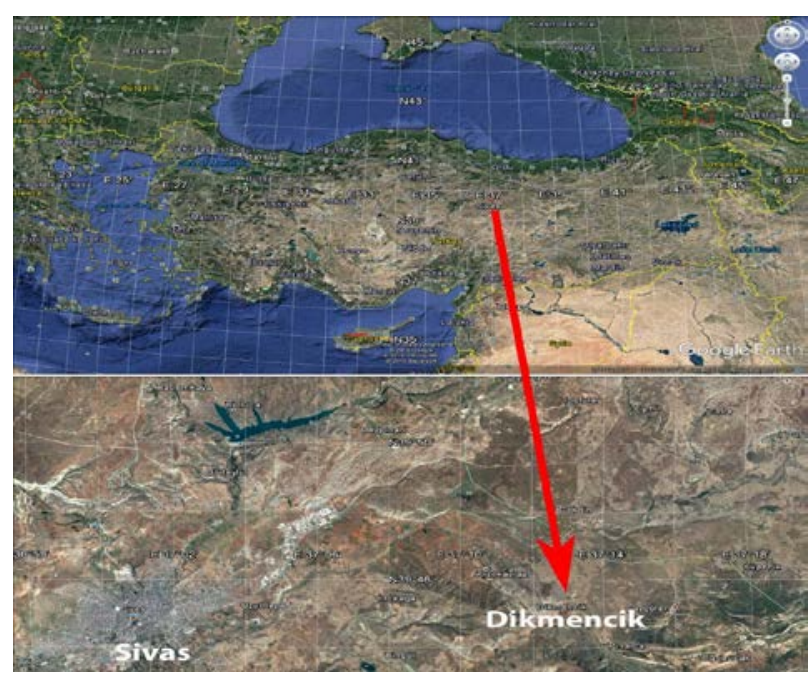

Şekil 1. Çalışma alanı

\section{YÖNTEM}

$\mathrm{Bu}$ çalışmada ağırlıklı çakıştırma yöntemi kullanılarak Sivas İli Merkez İlçe Dikmencik Köyü için en uygun arazi kullanım planlarını oluşturulmuştur. $\mathrm{Bu}$ planlar oluşturulurken 
kamu kurum ve kuruluşlarında çalışan uzmanlarla da (Ziraat ve Harita Mühendisleri) görüşmeler yapılmıştır. En uygun arazi kullanım planlamasinın verilerinin oluşturulması amaciyla çalışmada:

- Sivas Kadastro Müdürlüğü'nden elde edilen 1/5.000 lik Sayısal Kadastro Paftaları,

- Sivas İl Gida Tarım ve Hayvancılık Müdürlügü'nde bulunan toprağın kimyasal ve morfolojik özelliklerine ait 1/10000 ölçekli toprak envanteri haritaları,

-Verilerin işlenmesi ve haritalama işlemleri için ArcGIS 10.1 CBS yazılımı kullanılmıştır.

Ayrıca, ilgili resmi kurumların hazırladığı araştırma raporları da kullanılan yöntem içerisinde dikkate alınmıştır.

\subsection{Verilerin CBS Ortamına Aktarılması ve Analizi}

Çalışma bölgesine ait sayısal kadastro ve toprak envanteri haritaları CBS ortamına aktarılmıştır. Kamu kurum ve kuruluşlarında çalışan uzmanlarla da (Ziraat Mühendisi) görüşmeler yapılarak, en uygun arazi kullanım planlamasının oluşturulmasında hangi verilerinin kullanılması gerektiği ve konu ile ilgili ayrıntılı bilgiler elde edilmiştir. Bu doğrultu da 5403 Sayılı Toprak Koruma ve Arazi Kullanımı Kanunu kapsamında tarım alanlarının tanımı, sinıfi ve bu siniflara ait özellikleri belirlenmiştir. Belirlenen toprak verilerinden çalışma amacına uygun eğim, derinlik, erozyon, Büyük Toprak Grubu (BTG), kullanım durumu, Arazi Kullanım Planlaması (AKP) uygunluk sinıfları verileri mekânsal analiz yapılarak alan geometrisi ve sözel verilerden oluşan vektör veri formatında tanımlanmıştır. Vektörel veri formatında değeri olmayan sınıflara da değer atamak için çalışma alanı içerisindeki araziler için belirlenen derinlik, erozyon, BTG, mevcut arazi kullanım durumu, AKP vektör verileri gibi verileri raster verilere dönüşüm işlemi gerçekleştirilmiştir. Toprak etüdü ve toprak haritalarına ilişkin sayısal veri tabanının oluşturulmasında hukuki dayanak olarak 3083 Sayılı Sulama Alanlarında Arazi Düzenlenmesine dair Tarım Reformu Kanunu, 5403 Say1l Toprak Koruma ve Arazi Kullanımı Kanunu ile bu kanunlara ait yönetmelik ve talimat hükümleri baz alınmıştır. Çalışmaya konu olan Dikmencik Köyü 3083 Say11 Kanun Kapsamında uygulama alanı ilan edilen yerler arasinda olup bölgede Arazi Toplulaştırma ve Tarla içi Geliştirme Hizmetleri projesi devam etmektedir. $\mathrm{Bu}$ proje kapsamında bölgede proje çalışmalarından önce arazi etütleri yapılmış ve derecelendirme haritalarına göre toprak indeks ve dağıtıma esas derecelendirme haritaları oluşturulmuştur. $\mathrm{Bu}$ standartlar 5403 Sayılı Toprak Koruma ve Arazi Kullanımı Kanunu Ek 5'te yer almaktadır. Çalışmamızda altlık oluşturacak toprak indeks haritalarında ise şu andaki arazi kullanım durumu verileri kullanılarak "mevcut arazi kullanım" haritaları oluşturulmuştur. CBS ortamında oluşturulan verilerden yapılan analiz sonucunda en uygun arazi kullanım planı haritası oluşturularak karşılaştırılması yapılmıştır.

\section{2. Ölçütlerin Uygunluk Puanlarının Belirlenmesi}

Çok katmanlı ağırlıklı çakıştırma yönteminde kullanılacak vektör girdilerin normalize edilebilmesi için, ağırlıklı çakıştırma öncesi, eşit piksel büyüklüklerinde raster yapıya dönüştürülmeleri gerekmektedir. Normalize edilen katmanlar 'Map Algebra' yöntemi ile tanımlanan fonksiyonlarla bir arada değerlendirilen bir yöntemdir. Eşit piksel büyüklüklerinde raster yapıya dönüştürülen veriler yeniden sinıflandırılma işlemine tabii tutulmuştur. Yeniden sinıflandırma işleminde uzman görüşleriyle görüşülüp edinilen bilgiler doğrultusunda tarım, mera ve orman alanları için uygunluk puanları belirlenmiştir. 
Tablo 1. Tarım, mera ve orman alanları için belirlenen sınıflandırma değerleri

\begin{tabular}{|c|c|c|c|c|c|}
\hline \multicolumn{2}{|l|}{ Tarım } & \multicolumn{2}{|l|}{ Mera } & \multicolumn{2}{|l|}{ Orman } \\
\hline Hiç /hafif erozyon & 5 & Hiç /hafif erozyon & 1 & Hiç /hafif erozyon & 1 \\
\hline Orta erozyon & 3 & Orta erozyon & 2 & Orta erozyon & 2 \\
\hline Şiddetli erozyon & 2 & Şiddetli erozyon & 3 & Şiddetli erozyon & 4 \\
\hline Çok şiddetli erozyon & 1 & Çok şiddetli erozyon & 5 & Çok şiddetli erozyon & 5 \\
\hline $\begin{array}{l}110 \mathrm{~cm} \text { olan ve üzeri } \\
\text { derinlik }\end{array}$ & 5 & $110 \mathrm{~cm}$ olan ve üzeri derinlik & 1 & $\begin{array}{l}110 \text { cm olan ve üzeri } \\
\text { derinlik }\end{array}$ & 1 \\
\hline 75-109 cm olan derinlik & 3 & 75-109 cm olan derinlik & 2 & 75-109 cm olan derinlik & 2 \\
\hline $20-75 \mathrm{~cm}$ olan derinlik & 2 & $20-75 \mathrm{~cm}$ olan derinlik & 3 & $20-75 \mathrm{~cm}$ olan derinlik & 4 \\
\hline 0-20 cm olan derinlik & 1 & 0-20 cm olan derinlik & 4 & 0-20 cm olan derinlik & 5 \\
\hline Düz düze yakın (A) & 6 & Düz düze yakın (A) & 1 & Düz düze yakın (A) & 1 \\
\hline Hafif eğimli (B) & 5 & Hafif eğimli (B) & 2 & Hafif eğimli (B) & 2 \\
\hline Orta eğimli (C) & 4 & Orta eğimli (C) & 3 & Orta eğimli (C) & 3 \\
\hline Dik eğimli (D) & 3 & Dik eğimli (D) & 4 & Dik eğimli (D) & 4 \\
\hline Çok dik eğimli & 2 & Çok dik eğimli & 5 & Çok dik eğimli & 5 \\
\hline Sarp eğimli & 1 & Sarp eğimli & 6 & Sarp eğimli & 6 \\
\hline Aluvial & 2 & Aluvial & 3 & Aluvial & 1 \\
\hline Kahverengi & 3 & Kahverengi & 2 & Kahverengi & 2 \\
\hline K1rmızıms1 Kahverengi & 3 & Kırmızıms1 Kahverengi & 2 & Kirmızıms1 Kahverengi & 3 \\
\hline
\end{tabular}

\section{Kullanılan Ölçütlerin Ăğılık Puanlarının Belirlenmesi}

Değerlendirmeye alınan ölçütlerin uygunluk puanlarının verilmesinin ardından, ağırlıklı çakıştırma işlemi gerçekleştirilmiştir. $\mathrm{Bu}$ aşamada ölçütlerin birbirlerine göre önemi dikkate alınarak, uzman görüşünden edinilen bilgiler doğrultusunda en yüksek puan en uygun ölçüte atanırken, en düşük puan ise uygunlukta son sirada gelen ölçütlere atanmıştır. İşlem sonunda, tüm ölçütlerin ağırlıklı etkisine bağlı genel uygunluk haritaları oluşturulmuştur.

Tablo 2. Tarım, mera ve orman alanlarının ağırlıklı çakıştırma oranları

\begin{tabular}{|l|l|l|l|l|l|}
\hline \multicolumn{2}{|c|}{ Tarım } & \multicolumn{2}{c|}{ Mera } & \multicolumn{2}{c|}{ Orman } \\
\hline Derinlik & $\% 30$ & Derinlik & $\% 25$ & Derinlik & $\% 25$ \\
\hline Eğim & $\% 30$ & Eğim & $\% 15$ & Eğim & $\% 20$ \\
\hline Erozyon & $\% 10$ & Erozyon & $\% 25$ & Erozyon & $\% 25$ \\
\hline BTG & $\% 10$ & BTG & $\% 10$ & BTG & $\% 15$ \\
\hline AKP uygunluk & $\% 20$ & AKP uygunluk & $\% 25$ & AKP uygunluk & $\% 15$ \\
\hline
\end{tabular}

\footnotetext{
* Sorumlu Yazar

Bu çalışma IX. TUFUAB 2017 Teknik sempozyumunda sunulmuş olup başka bir yerde yayınlanmamıştır.
} 

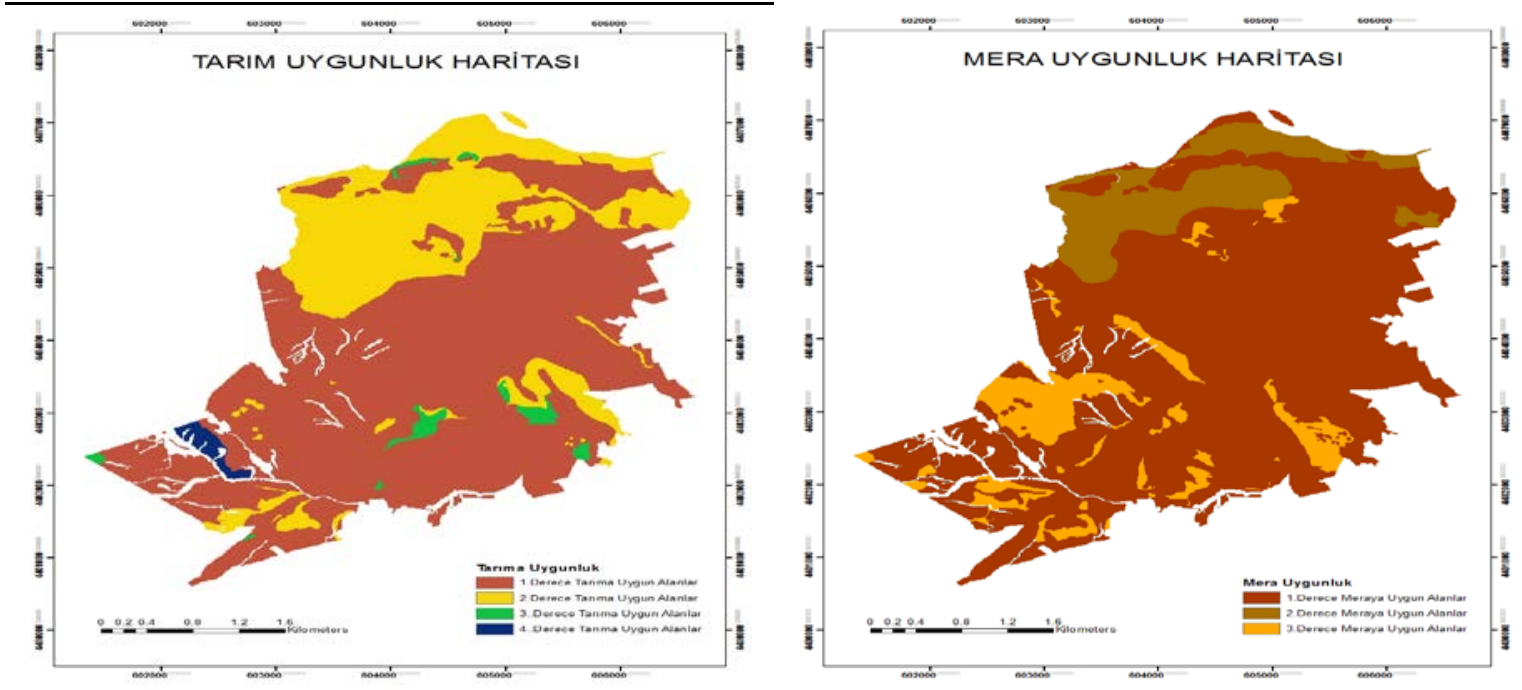

Şekil 2. Tarıma uygunluk ve Mera uygunluk Haritaları

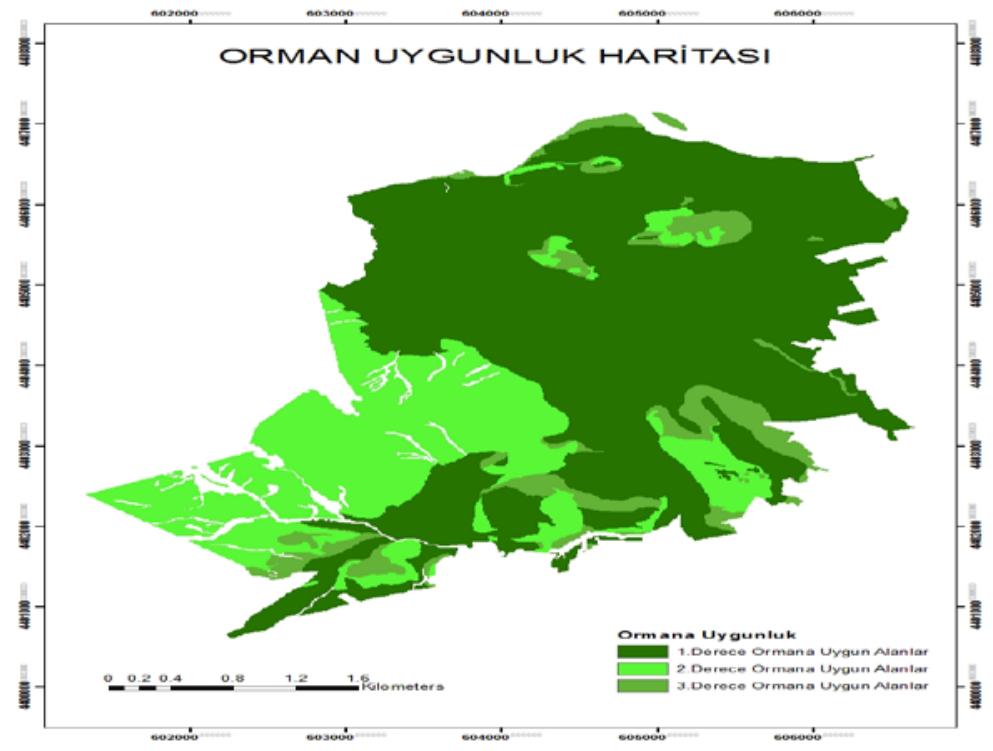

Şekil 3. Orman uygunluk Haritas1

\section{BULGULAR}

Arazi kullanımları için arazi uygunluk çözümlemelerinde belirleyici olabilecek üst ve alt ölçütler seçilirken, çalışma alanı için mevcut haritalar dikkate alınmıştır. $\mathrm{Bu}$ ölçütler ile her bir ölçüte ait alt ölçütlere yönelik gerekli açılamalar aşağıda sunulmuştur.

Eğimin Etkisi: Arazinin eğimi birçok bakımdan önemli olup arazinin engebelilik derecesini ifade etmektedir. Eğim derecesinin fazla olması bir taraftan erozyon tehlikesini artırırken diğer taraftan infiltrasyon, bitki seçimi ve sulama yöntemini etkilemektedir. Arazi etüt ölçütlerinde \% 0-2, \% 2-4, \% 4-6,
\% 6-12 eğimli alanlar tarımsal nitelik alanları içerisinde belirlenmiştir. Tarımsal arazilerin genelde \% 0-6 eğim aralığında olduğu buna karşın \% 12 ve daha yüksek eğimli alanların mera ya da orman arazilerini kapsadığ 1 ve arazi kullanım durumunda eğim özelliklerinin bu yönü ile belirleyici bir faktör olduğu görülmektedir. Diğer taraftan eğimin olmaması veya çok az olması drenaj üzerinde olumsuz etki yapabilir (5403 Sayılı Kanun). Tarımsal uygunlukta eğimi az olan yerler genel anlamda tarım için daha elverişlidir.

Erozyon Etkisi: Erozyon, ana hatları ile üst toprak yapısının rüzgâr ve su yardımıyla kütleler halinde taşınmasıdır. Taşınmayı gerçekleştiren faktörlerin başında su, rüzgâr 
ve buzullar gelmektedir. Erozyon, toprağın dokusal yapısını kökleri vasıtası ile tutan bitkisel örtünün ortadan kaldırılması, yoğun yağışlar, aşırı otlatma, uygun olmayan tarımsal teknik ve yoğun toprak işleme ile bilgisiz arazi kullanması sonucunda şiddetlenmektedir. Eğim derecesi yükseldikçe erozyon zararı da artmaktadır (5403 sayılı kanun). Tarımsal uygunlukta erozyon toprağın kalite ve sinıflandırılmasına etki etmektedir. Tarımsal uygunlukta erozyonu düşük alanlar tarım için elverişlidir.

Toprak Derinliğin Etkisi: Etkili toprak derinliği; Bitkilerin kökleri vasıtası ile su ve besin maddelerinden yararlanabildiği derinlik anlamına gelmektedir. Toprak derinliği oluştukları ana kayanın özelliklerine, bitki örtüsüne, yeryüzü şekline, iklim özelliklerine ve canlıların fiziksel etkilerine bağlı olarak değişmektedir (5403 Sayılı Kanun). Toprak derinliği tarım için belirleyici bir faktördür. Toprak derinliği ile tarımsal verim doğru orantılı olup toprak derinliği artıkça tarımsal üretim ve potansiyel de buna bağlı olarak artmaktadır.

\section{Büyük Toprak Grupları (BTG)}

Alüvyal Topraklar: Bu topraklar aşırı toprak rutubeti ile karakterize edilir. Orman alanlarının bittiği yerde, çeşitli ana maddelerden, bozuk drenaja sahip alanlarda ve soğuk iklim şartlarında oluşmuştur. Üstte koyu renkli bir katman, altında daha gri renkli toprak bulunmaktadır. Üzerlerindeki doğal bitki örtüsü genellikle otsu ve çiçekli bitkiler ile sazlık alanlardır. Soğuk iklimden dolayı verimleri sınırlıdır. Çoğunlukla yazın otlatmada kullanılırlar. (5403 sayılı kanun toprak sinıflandırması teknik talimatı )

Kahverengi Topraklar: Bu topraklar daha çok kurak ve yarı kurak iklimlerde bulunmakta olup üzerlerindeki doğal bitki örtüsü genelde kısa ot ve çalılardan ibarettir. Kalsiyum ve bitki besin elementleri bakımından zengindirler. Doğal drenajları iyidir (5403 sayılı kanun toprak sınıflandırması teknik talimatı).
Kırmızımsı Kahverengi Topraklar: Renk hariç, hemen hemen bütün özellikleri Kahverengi toprakların birebir aynı veya benzer grubunda yer almaktadırlar. $\mathrm{Bu}$ topraklar kurak ve yarı kurak iklimlerde bulunurlar. Doğal bitki örtüsü ot ve çalılar olup drenaj durumları iyidir. Bu topraklarda biyolojik etkinlik düşük olup doğal verimleri nispeten yüksektir (5403 sayılı kanun toprak sinıflandırması teknik talimatı).

Yukarıda belirtilen açıklamalar dikkate alınarak tüm parametrelere ilişkin haritalar üretilmiştir.

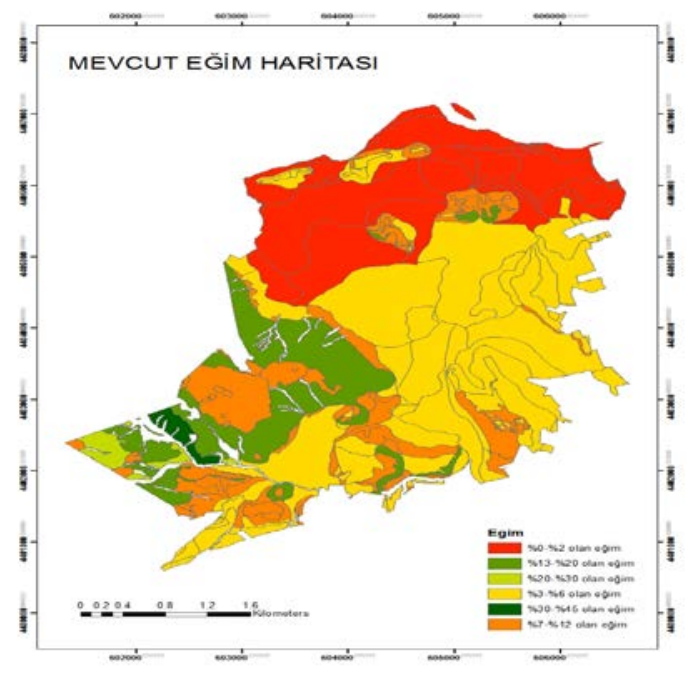

Şekil 5. Mevcut Eğim Haritası

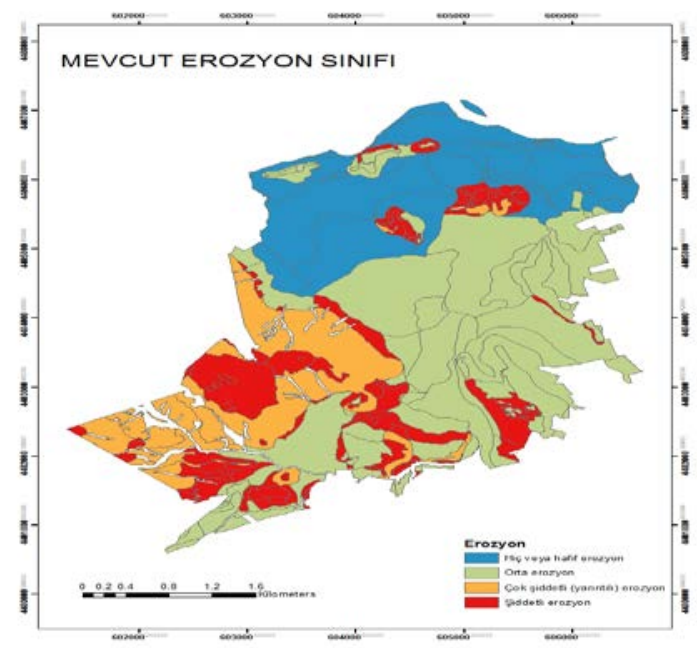

Şekil 6. Mevcut Erozyon Haritası 


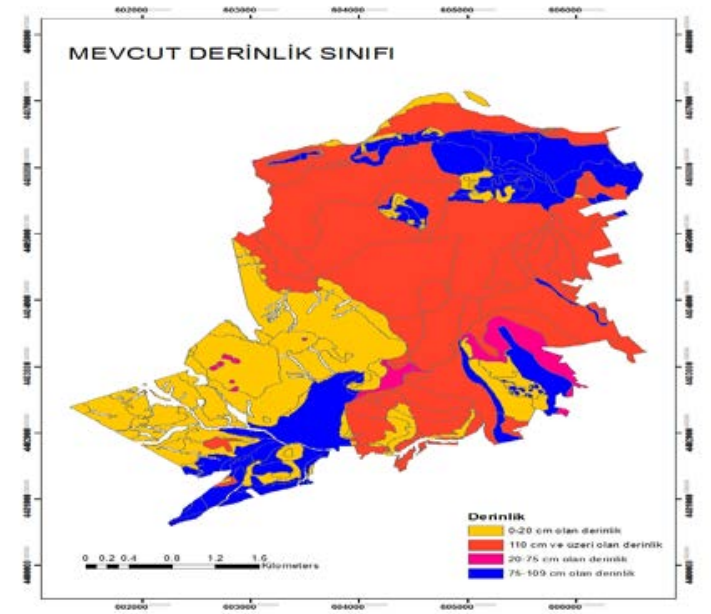

Şekil 6. Mevcut Derinlik Haritası

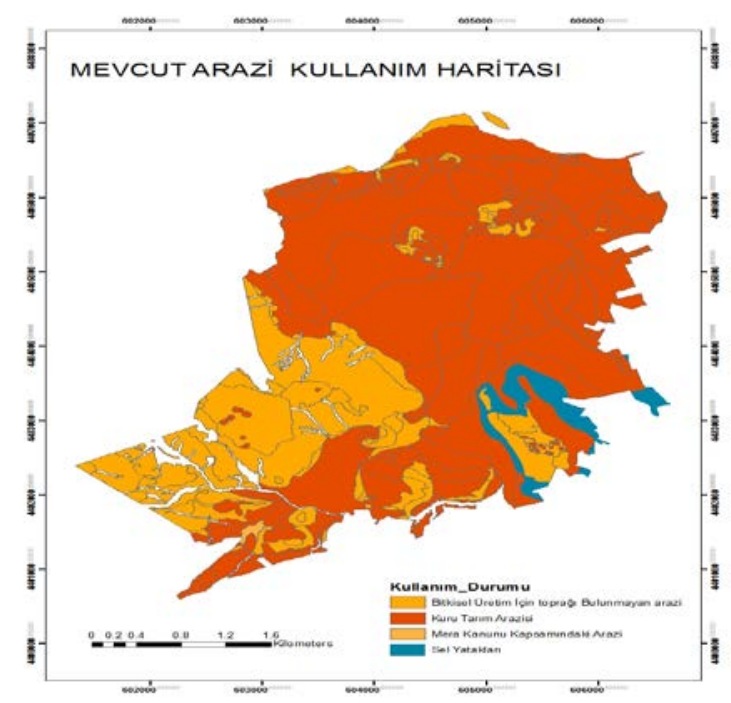

Şekil 8. Mevcut Arazi Kullanım Haritası

\section{SONUÇLAR ve TARTIŞMA}

Çalışma alanında yapılan analizler neticesinde arazinin doğal yetenek ve kabiliyetlerine göre değerlendirilmesi yapılmış ve en uygun arazi kullanım planı oluşturulmuştur. $\mathrm{Bu}$ amaçla arazinin doğal yetenek ve kabiliyet kullandırılması esas alınmıştır.

Mevcut tarım arazileri kullanımı 12,30 ha iken en uygun arazi kullanım planlaması sonucu 10,62 ha olarak belirlenmiştir. Mevcut mera arazileri kullanımı 13,46 ha iken en uygun arazi kullanım planlamas1 sonucu 6,5 ha olarak tespit edilmiştir. Diğer taraftan mevcut orman arazileri kullanımı 1,1 ha iken en uygun arazi kullanım planlaması sonucu 0,18 ha olarak belirlenmiştir. Elde edilen sonuçlara göre mevcut arazi kullanımında bulunan tarım, mera ve orman alanlarının en uygun arazi kullanım planlarında bulunan

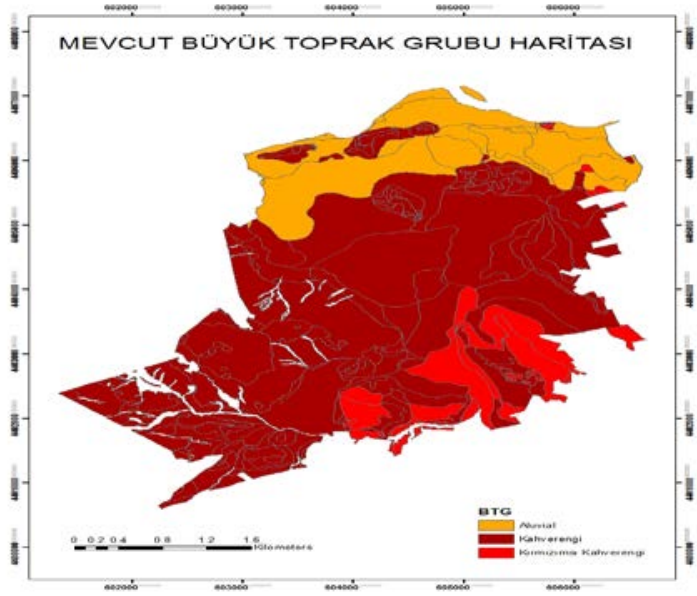

Şekil 7. Mevcut BTG Haritası

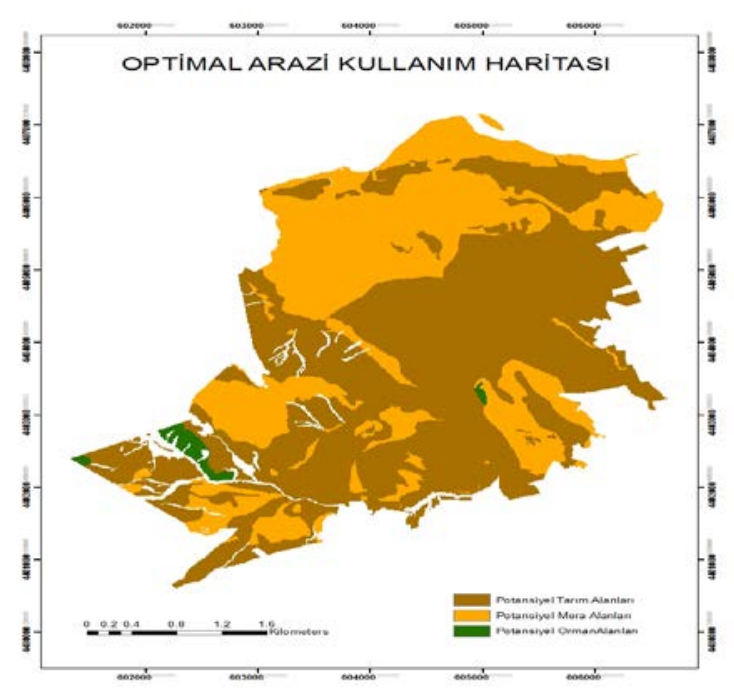

Şekil 9. En uygun Arazi Kullanım Haritası

tarım, mera ve orman alanlarından daha fazla olduğu ortaya konulmuştur. Buna göre analizi yapılan Sivas İli Merkez İlçe Dikmencik köyündeki arazilerin büyük bir bölümünün en uygun arazi planlamasına uygun bir şekilde kullanılmadığı belirlenmiştir.

Arazilerin belirlenen en uygun arazi kullanım planlarına uygun olarak kullanımı doğal kaynakların, toprağın ve suyun korunması, tarımsal üretimde verimlilik ve kalitenin artırılması, üretim planlaması ile bitkisel üretim deseninin ortaya çıkarılması için gereklidir. $\mathrm{Bu}$ planlamaların yapılması ve yaygınlaştırılması ile kırsal kalkınmanın başlatılarak kırsaldan göçün önüne geçilmesi sağlanabilecektir. 
NOT: $\mathrm{Bu}$ çalışma Afyon Kocatepe Üniversitesinde 27- 29 Nisan 2017 tarihleri arasında gerçekleştirilen TUFUAB IX. Teknik Sempozyumununda sunula ve yeniden hakemlik sürecinden geçirilerek Kabul edilmiș halidir.

\section{KAYNAKÇA}

Akten M., 2008. Isparta ovasının optimal alan kullanım planlaması üzerine bir araştırma. Süleyman Demirel Üniversitesi, Fen Bilimleri Enstitüsü, Orman Mühendisliği Anabilim Dal, Doktora tezi, Isparta.

Cengiz T., Akbulak C., Özcan H.,Beytekin H., 2013. Gökçeada'da Optimal Arazi Kullanımının Belirlenmesi. Tarım Bilimleri Dergisi: 149-162

Akbulak C., 2010. Analitik Hiyerarşi Süreci ve Coğrafi Bilgi Sistemleri ile Yukarı Kara Menderes Havzası'nın Arazi Kullanımı Uygunluk Analizi. Uluslararası İnsan Bilimleri dergisi :558-576

Cengiz T \& Akbulak C (2009). Application of analytical hierarchy process and geographic information systems in landuse suitability evaluation: a case study of Dümrek village (Çanakkale, Turkey). International Journal of Sustainable Development \& World Ecology 16(4): 286-294

Zengin M (2007). Ardahan Kura Nehri ve yakın çevresi alan kullanımlarının belirlenmesi ve optimal alan kullanım önerileri. Doktora tezi, Atatürk Üniversitesi Fen Bilimleri Enstitüsü Peyzaj Mimarlı̆̆ Anabilim Dalı (Basılmamış), Erzurum.

5403 Sayılı Toprak Koruma ve Arazi Kullanımı Kanunu. 19 Temmuz 2005 Tarihli, 25880 Sayılı Resmi Gazete.

URL1, 2017. T.C. Orman Genel Müdürlüğü, Doğu Akdeniz Ormancılık Araştırma Enstitüsü Müdürlüğü internet sayfası. http://doa.ogm.gov.tr/SitePages/OGM/OG MDefault.aspx

URL2, 2017. Çanakkale İl Tarım Gida ve Hayvancılık İl Müdürlüğü internet sayfası. http://canakkale.tarim.gov.tr/ 